\title{
Human Development Index Forecasting using Exponentially Weighted Moving Average
}

\author{
Seng Hansun, Marcel Bonar Kristanda
}

\begin{abstract}
Human Development Index (HDI) is an indicator to see the ruling government achievement, especially in the human development aspect. It was introduced by United Nations Development Programme (UNDP) in their 1990 report and integrated three basic dimensions of human development, i.e., the ability to lead a long and healthy life, to acquire knowledge, and to achieve a decent standard of living. Indonesia itself was ranked 113 out of 188 UNDP countries and ranked fifth among ASEAN countries for HDI value based on UNDP Human Development Re-port 2016: Human Development for Everyone. In this study, we are trying to forecast Indonesia's HDI using Exponentially Weighted Moving Average (EWMA) method. EWMA is a popular and widely used method to smooth out random fluctuations. Based on the experiments conducted in 34 provinces in Indonesia, EWMA has been successfully applied to forecast the human development index in Indonesia. It has an average score of MSE and MAPE values at 1.002279153 for MSE and $1.374754513 \%$ for MAPE.
\end{abstract}

Index Terms: Exponentially Weighted Moving Average, Forecasting, Human Development Index, Indonesia's provinces.

\section{INTRODUCTION}

One indicator to see the successfulness of a government, especially in the human development aspect, is by looking at the Human Development Index (HDI) value. It is an indicator to measure the citizen's physic and non-physic qualities [1]. The higher the value means the better life quality of citizen of

HDI was first introduced by the United Nations Development Programme (UNDP) in 1990 in their report Human Development Report - and has been used every year until now [2, 3]. It integrates three basic dimensions of human development, i.e., the ability to lead a long and healthy life, the ability to acquire knowledge, and the ability to achieve a decent standard of living [4].

According to 2016 UNDP Human Development Report, the country-level trends on HDI have been impressive over the past 25 years, where the number of countries classified as having low human development fell from 62 to 41 and those classified as having very high human development rose from

Revised Manuscript Received on October 30, 2019

* Correspondence Author

Seng Hansun*, Informatics Department, Universitas Multimedia Nusantara, Tangerang, Indonesia

Marcel Bonar Kristanda, Informatics Department, Universitas Multimedia Nusantara, Tangerang, Indonesia

(C) The Authors. Published by Blue Eyes Intelligence Engineering and Sciences Publication (BEIESP). This is an open access article under the CC BY-NC-ND license (http://creativecommons.org/licenses/by-nc-nd/4.0/) a nation's has.

11 to 51 [4]. Figure 1 shows the regional trends in HDI values taken from UNDP's report.

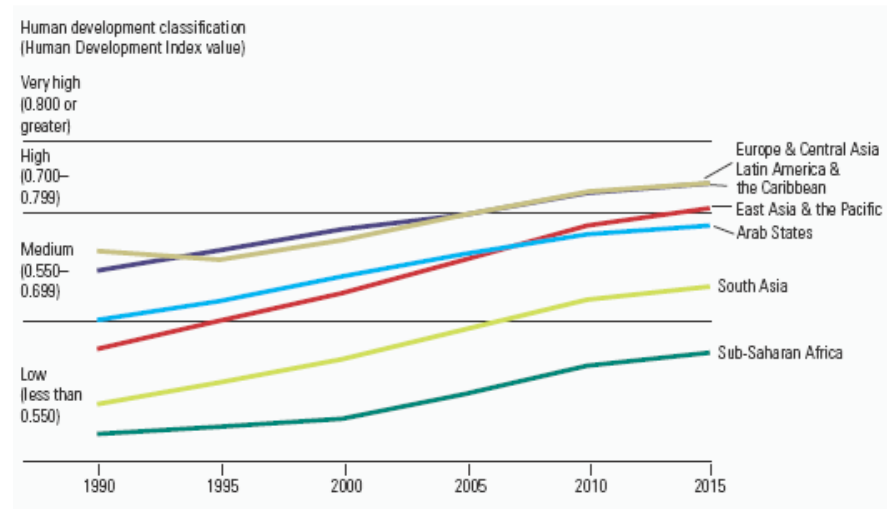

Fig. 1. Regional trends in Human Development Index Values [4]

On 2015, Indonesia was ranked 113 among 188 countries by HDI rank, which was classified as having medium human development [4]. Among the Association of Southeast Asia Nations (ASEAN) countries, however, Indonesia was ranked fifth after Singapore, Brunei Darussalam, Malaysia, and Thailand [3]. Figure 2 shows the position of Indonesia among other ASEAN countries.

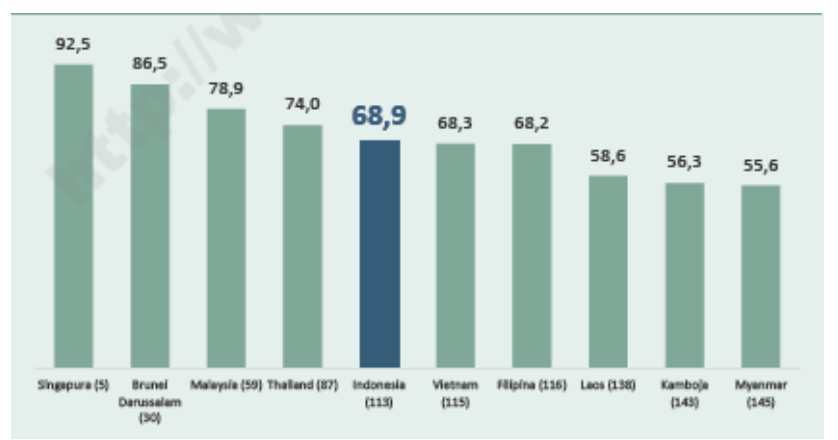

Fig. 2. ASEAN Countries HDI [3]

There are still so many works to do by the Indonesia government and citizen to bring a better life quality for all its' people. Ramani [5] also had conducted a research to see the correlation between HDI with other rate indexes in the environment, disease, and nutrition fields and found that there is a significant statistical relation between HDI with other rate indexes, whether in positive or negative form.

In this research, the authors would like to forecast future HDI value, especially for different provinces in the Republic of Indonesia.

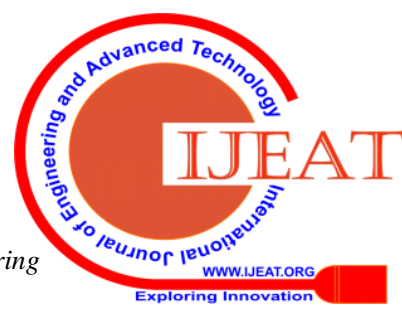


By forecasting HDI values, we could learn which provinces have an increasing or decreasing index value, and take a better counter-measurement for improving human life qualities of Indonesia's citizen.

A popular and widely-known forecasting method, i.e., moving averages (MA) method [6], which has some variations, was used in the research. Simple moving average (SMA), weighted moving average (WMA), and exponentially weighted moving average (EWMA) are some of MA methods which have been accepted and used in time series forecasting, as can be seen from researches conducted by Kapgate [7], Zhuang et al. [8], Ren et al. [9], and Cadenas et al. [10].

In particular, EWMA, which is also known as exponential moving average (EMA), is a special type of MA that uses an exponential function as the basis in forming the weighting factors for forecasting. It is a means to smooth out random fluctuations that has the following properties: (1) declining weight is put on older data, (2) it is extremely easy to compute, and (3) minimum data is required [11]. Therefore, it is suitable to be used in forecasting Indonesia HDI, which has small data for each province and linear trend. Furthermore, mean square error (MSE) and mean absolute percentage error (MAPE) are used to calculate the error differences between the real data and predicted data.

Section 2 will discuss briefly on the forecasting method implemented in this research together with the three forecast error measurements which had been mentioned before. In section 3, we will explain first the pre-processing phase of the data, i.e., HDI value for each province in Indonesia, followed by the forecasting results of HDI and evaluation using MSE and MAPE. The experimental results will be analyzed and concluded in the last section.

\section{EWMA, MSE, AND MAPE}

In this section, a brief explanation of the forecasting method used in this study, i.e., EWMA, will be given. The two forecast error measurements, i.e., MSE and MAPE, as evaluation criteria to get the accuracy level of the forecasting results will also be discussed.

\section{A. Exponentially Weighted Moving Average}

EWMA was originated from Robert G. Brown's work, who was assigned by the US Navy to develop a tracking model for fire-control information on the location of submarines [12]. It puts greater weight on more recent data than the older ones. EWMA for time series $Y$ can be calculated recursively using [13]:

$$
\begin{gathered}
S_{1}=Y_{1} \\
\text { for } t>1, S_{t}=\alpha \cdot Y_{t}+(1-\alpha) \cdot S_{t-1}
\end{gathered}
$$

where $Y_{t}$ is the value at time period $t, S_{t}$ is EWMA value at time $t$, and $\alpha$ is a constant smoothing factor with a range value between 0 and 1. As suggested by Johnston et al. [14], $\alpha$ can be estimated as:

$$
\alpha=\frac{2}{n+1}
$$

However, in this study, we will try to find the best $\alpha$ value using a brute force approach, which minimizes the error rate of forecasting results.

\section{B. Mean Square Error}

MSE is the average of squared error sum which can be found by differencing the actual (real) data with the forecasted one. Eq. (4) shows the formula for MSE [15]:

$$
M S E=\frac{1}{n} \sum_{t=1}^{n}\left(A_{t}-F_{t}\right)^{2}
$$

where $n$ refers to the total number of data, $A_{t}$ is the actual value of data, and $F_{t}$ is the forecasted value of data.

\section{Mean Absolute Percentage Error}

MAPE is the average of absolute error sum between the forecasted and real data, divided by the real data. As described by Alsultanny [15], MAPE can be found using:

$$
M A P E=\left(\frac{1}{n} \sum_{t=1}^{n}\left|\frac{A_{t}-F_{t}}{A_{t}}\right|\right) \cdot 100 \%
$$

where $n$ refers to the total number of data, $A_{t}$ is the actual value of data, and $F_{t}$ is the forecasted value of data.

\section{RESULTS AND DISCUSSIONS}

This section is started with the explanation of Indonesia's HDI data pre-processing. Then, we depict the forecasting results of HDI value for each province in Indonesia and finish it with some evaluation and analysis of the results.

\section{A. Data Pre-Processing}

The data have been used in this study is Indonesia's HDI or Indeks Pembangunan Manusia (IPM) in Bahasa Indonesia. We collect the data from Badan Pusat Statistik (BPS) Statistics Indonesia [16]. They give Indonesia's HDI values for each province in Indonesia from 2010-2016. A total number of 238 records were taken for all 34 provinces, but three records of them are missing, i.e., 2010-2012 HDI values for Kalimantan Utara province. HDI data from 2010-2015 of each province will be used to forecast 2016 HDI values and compare it with the real data. HDI itself can be calculated using Eq. (6). Interested readers are encouraged to see references [2-3].

$$
H D I=\frac{\left(X_{1}+X_{2}+X_{3}\right)}{3}
$$

where $X_{1}$ is the index value of life expectancy, $X_{2}$ is the index value of knowledge or education, and $X_{3}$ is the index value of a decent standard of living.

\section{B. Forecasting Results}

Figure 3 to Figure 5 show the graphs of forecasting results of Sumatera Barat, DKI Jakarta, and Sulawesi Utara, Kalimantan Selatan, and Papua provinces, respectively. We won't show all the forecasting results graphs, but the mentioned provinces are assumed to represent all provinces of Indonesia which are scattered on five different islands. Furthermore, the experiments were also conducted on a web-based application called Phatsa, which can be accessed for free on http://phatsa.com/ [17]. 


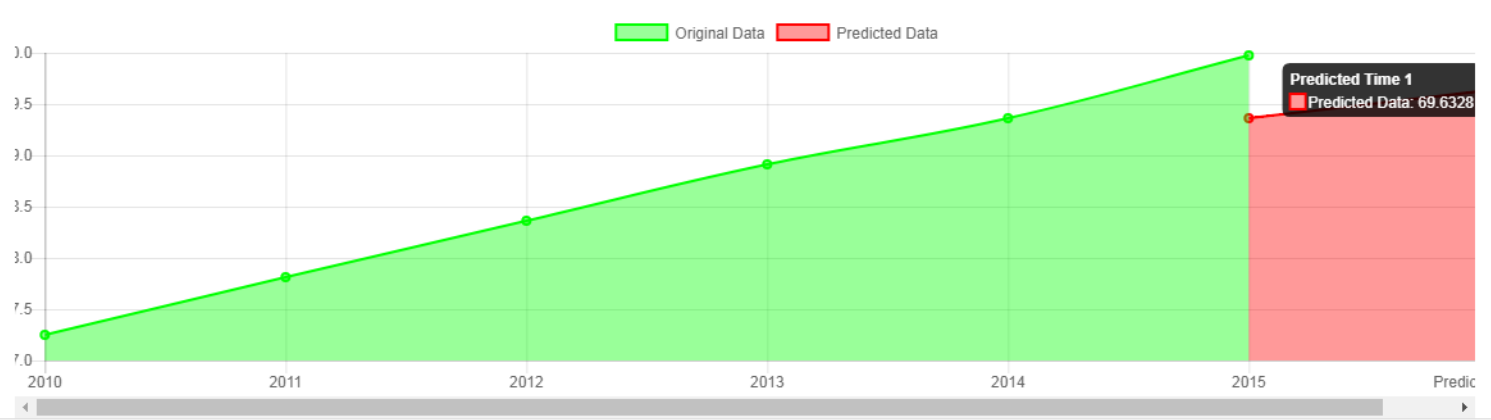

Fig. 3. 2016 HDI forecasting result for Sumatera Barat

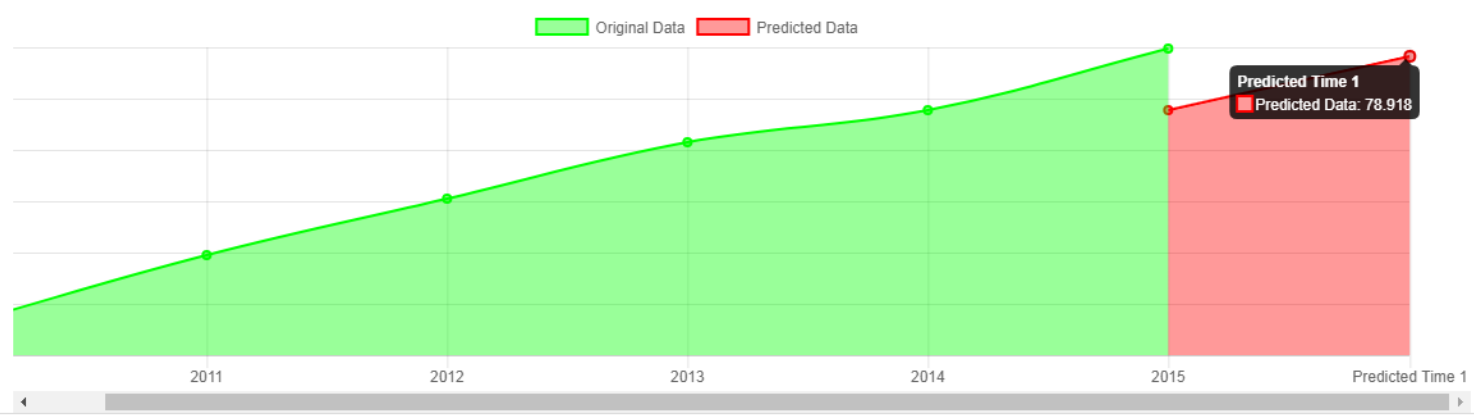

Fig. 4. 2016 HDI forecasting result for DKI Jakarta

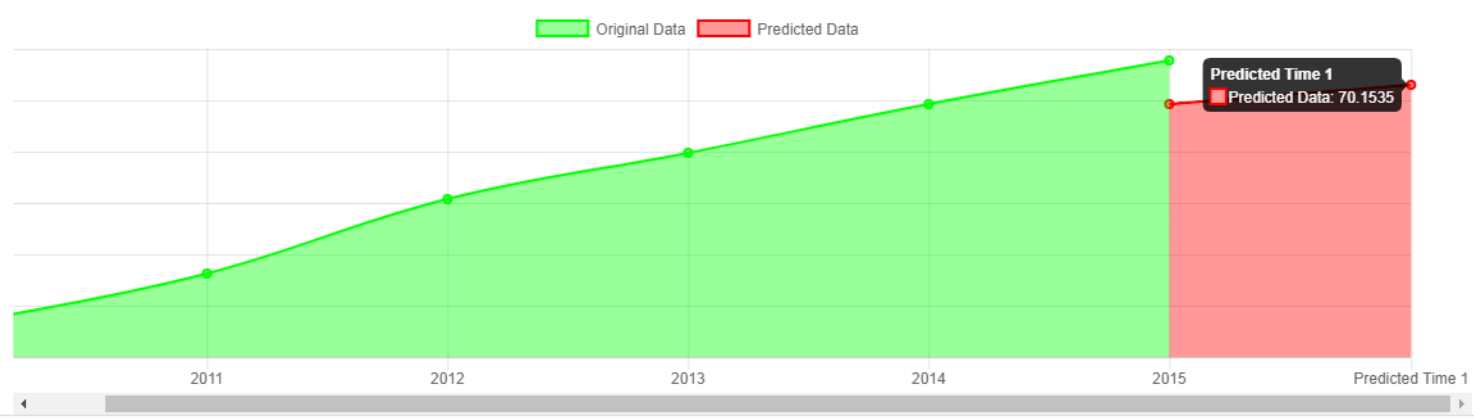

Fig. 5. 2016 HDI forecasting result for Sulawesi Utara

\section{Evaluation}

All 34 provinces' HDI in Indonesia have been forecasted using Phatsa. The HDI forecasting results for 2016 are shown in Table 1. The differences between actual data and forecasted data also had been shown in Table 1 so that we can calculate the MSE and MAPE values of the forecasting results using EWMA method. It is shown that the forecasting results of HDI values for 34 provinces have a quite small MSE and MAPE values, i.e., 1.002279153 for MSE and $1.374754513 \%$ for MAPE. Therefore, EWMA can be used as a forecasting method to predict future HDI values in Indonesia's provinces.

Table 1. 2016 Indonesia's HDI Forecasting Results

\begin{tabular}{cccccc}
\hline Province & $\begin{array}{c}\text { Actual } \\
\text { HDI }\end{array}$ & $\begin{array}{c}\text { Forecasted } \\
\text { HDI }\end{array}$ & $\boldsymbol{A}_{\boldsymbol{t}}-\boldsymbol{F}_{\boldsymbol{t}}$ & $\left(\boldsymbol{A}_{\boldsymbol{t}}-\boldsymbol{F}_{\boldsymbol{t}}\right)^{\mathbf{2}}$ & $\left|\frac{\boldsymbol{A}_{\boldsymbol{t}}-\boldsymbol{F}_{\boldsymbol{t}}}{\boldsymbol{A}_{\boldsymbol{t}}}\right|$ \\
\hline ACEH & 70 & 68.842 & 1.158 & 1.340964 & 0.016542857 \\
SUMATERA UTARA & 70 & 68.9212 & 1.0788 & 1.16380944 & 0.015411429 \\
SUMATERA BARAT & 70.73 & 69.6328 & 1.0972 & 1.20384784 & 0.015512512 \\
RIAU & 71.2 & 70.8043 & 0.3957 & 0.15657849 & 0.005557584 \\
JAMBI & 69.62 & 68.5325 & 1.0875 & 1.18265625 & 0.015620511 \\
SUMATERA SELATAN & 68.24 & 66.7713 & 1.4687 & 2.15707969 & 0.021522567 \\
BENGKULU & 69.33 & 68.0865 & 1.2435 & 1.54629225 & 0.017935958 \\
LAMPUNG & 67.65 & 66.6426 & 1.0074 & 1.01485476 & 0.014891353 \\
\hline
\end{tabular}




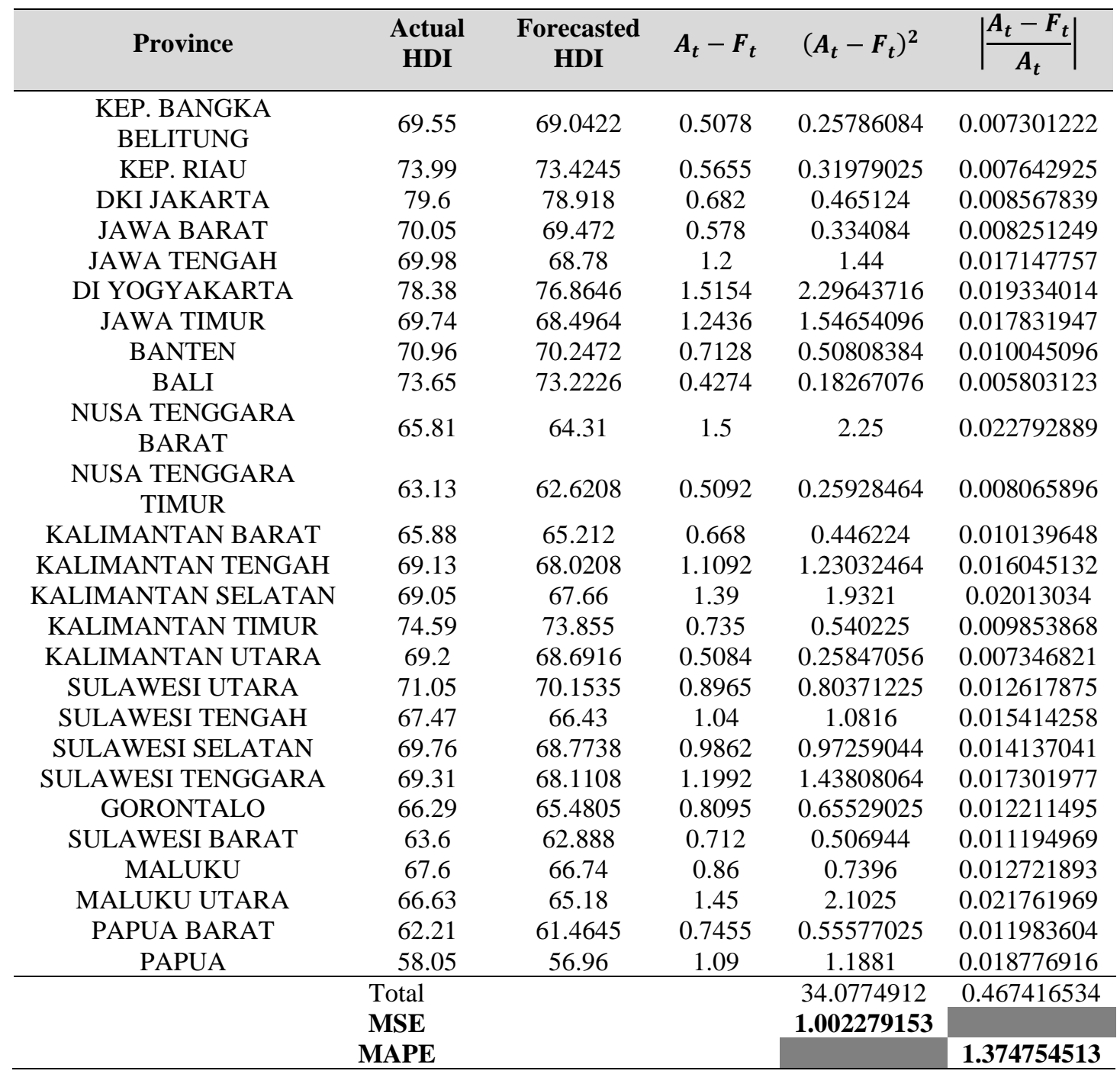

Moreover, based on HDI data for 2010-2016, we can calculate the percentage development of HDI for each province in Indonesia. As explained in [3], Eq. (7) can be used to calculate the percentage development of HDI.

$$
\% H D I \text { development }=\frac{H D I_{t}-H D I_{t-1}}{H D I_{t-1}} \times 100 \%
$$

where $H D I_{t}$ is a region's HDI value at year $t$ and $H D I_{t-1}$ is a region's HDI value at year $t-1$.

The average percentage development of all provinces in Indonesia is $0.854221 \%$. Accordance with [3], Papua, Sumatera Selatan, and Jawa Timur are three provinces with the highest development of HDI during 2015-2016. On the other hand, five provinces with the lowest development of HDI during 2015-2016 are Kep. Riau, Kalimantan Barat, Riau, Bali, and Kalimantan Timur. Table 2 shows five provinces with the lowest human development in Indonesia (depicted by orange fill color). There could be many aspects that influence these results. Therefore, further researches need to be done to know what are the main factors that make human development progress in those provinces not increased as much as Indonesia's government targets.

Table 2. HDI Development of Each Province in Indonesia

\begin{tabular}{clrrr}
\hline No & \multicolumn{1}{c}{ Province } & 2015 HDI & 2016 HDI & \% development \\
\hline 1 & ACEH & 69.45 & 70 & 0.791937 \\
2 & SUMATERA UTARA & 69.51 & 70 & 0.704935 \\
3 & SUMATERA BARAT & 69.98 & 70.73 & 1.071735 \\
4 & RIAU & 70.84 & 71.2 & 0.508187 \\
5 & JAMBI & 68.89 & 69.62 & 1.05966 \\
6 & SUMATERA SELATAN & 67.46 & 68.24 & 1.156241 \\
7 & BENGKULU & 68.59 & 69.33 & 1.078874 \\
8 & LAMPUNG & 66.95 & 67.65 & 1.045556 \\
9 & KEP. BANGKA BELITUNG & 69.05 & 69.55 & 0.724113 \\
\hline
\end{tabular}




\begin{tabular}{llrrr}
\hline 10 & KEP. RIAU & 73.75 & 73.99 & 0.325424 \\
11 & DKI JAKARTA & 78.99 & 79.6 & 0.77225 \\
12 & JAWA BARAT & 69.5 & 70.05 & 0.791367 \\
13 & JAWA TENGAH & 69.49 & 69.98 & 0.705137 \\
14 & DI YOGYAKARTA & 77.59 & 78.38 & 1.018172 \\
15 & JAWA TIMUR & 68.95 & 69.74 & 1.145758 \\
16 & BANTEN & 70.27 & 70.96 & 0.981927 \\
17 & BALI & 73.27 & 73.65 & 0.51863 \\
18 & NUSA TENGGARA BARAT & 65.19 & 65.81 & 0.951066 \\
19 & NUSA TENGGARA TIMUR & 62.67 & 63.13 & 0.734004 \\
20 & KALIMANTAN BARAT & 65.59 & 65.88 & 0.442141 \\
21 & KALIMANTAN TENGAH & 68.53 & 69.13 & 0.875529 \\
22 & KALIMANTAN SELATAN & 68.38 & 69.05 & 0.979819 \\
23 & KALIMANTAN TIMUR & 74.17 & 74.59 & 0.566267 \\
24 & KALIMANTAN UTARA & 68.76 & 69.2 & 0.639907 \\
25 & SULAWESI UTARA & 70.39 & 71.05 & 0.937633 \\
26 & SULAWESI TENGAH & 66.76 & 67.47 & 1.063511 \\
27 & SULAWESI SELATAN & 69.15 & 69.76 & 0.88214 \\
28 & SULAWESI TENGGARA & 68.75 & 69.31 & 0.814545 \\
29 & GORONTALO & 65.86 & 66.29 & 0.6529 \\
30 & SULAWESI BARAT & 62.96 & 63.6 & 1.016518 \\
31 & MALUKU & 67.05 & 67.6 & 0.820283 \\
32 & MALUKU UTARA & 65.91 & 66.63 & 1.092399 \\
33 & PAPUA BARAT & 61.73 & 62.21 & 0.77758 \\
34 & PAPUA & 57.25 & 58.05 & 1.39738 \\
\hline & & & & $\mathbf{0 . 8 5 4 2 2 1}$ \\
\hline
\end{tabular}

\section{CONCLUSION}

This paper describes the usage of EWMA method to forecast Indonesia's Human Development Index (HDI) in 34 provinces. HDI values for all 34 provinces have been successfully forecasted with a small MSE and MAPE values, i.e., 1.002279153 and $1.374754513 \%$ respectively. Therefore, the EWMA method can be used to forecast Indonesia's HDI values for a period ahead. Another finding from the research is that all provinces in Indonesia have a rising linear trend for HDI development. However, some provinces have a low HDI percentage development due to its low development on three basic dimensions of human development, i.e., the ability to lead a long and healthy life, the ability to acquire knowledge, and the ability to achieve a decent standard of living. Further researches can be done to investigate the factors that make the HDI progress on those provinces not increased significantly.

\section{ACKNOWLEDGEMENT}

We would like to thank Ministry of Research, Technology and Higher Education of the Republic of Indonesia (Kemenristekdikti) who has sponsored this research under the 'Applied Product Research' (Penelitian Produk Terapan) grant, contract no. 425/LPPM-UMN/IV/2017.

\section{REFERENCES}

1. Lumbantoruan EP \& Hidayat P, “Analisis Pertumbuhan Ekonomi dan Indeks Pembangunan Manusia (IPM) Provinsi-Provinsi di Indonesia (Metode Kointegrasi)," Jurnal Ekonomi dan Keuangan, vol. 2, no. 2, pp. 14-27, 2014.

2. Setiawan MB \& Hakim A, "Indeks Pembangunan Manusia Indonesia," Jurnal Economia, vol. 9, no. 1, pp. 18-26, 2013.

3. Nugroho A, Indeks Pembangunan Manusia 2016, Indonesia: Badan Pusat Statistik, 2016.

4. Human Development Report 2016 Team, Human Development Report 2016: Human Development for Everyone, USA: UNDP, 2016.
5. Ramani A, "Hubungan Indeks Pembangunan Manusia dengan Indikator Penyakit, Lingkungan, dan Gizi Masyarakat (Analisis Data Sekunder Negara Anggota UNDP)," Jurnal IKESMA, vol. 10, no. 1, pp. 13-21, 2014.

6. Zhu Y \& Zhou G, "Technical Analysis: An Asset Allocation Perspective on the Use of Moving Averages," Journal of Financial Economics, vol. 92, no. 3, pp. 519-544, 2009.

7. Kapgate D, "Weighted Moving Average Forecast Model based Prediction Service Broker Algorithm for Cloud Computing," International Journal of Computer Science and Mobile Computing, vol. 3, no. 2, pp. 71-79, 2014.

8. Zhuang Y, Chen L, Wang XS, \& Lian J, "A Weighted Moving Average-based Approach for Cleaning Sensor Data," in Proc. of $27^{\text {th }}$ International Conference on Distributed Computing Systems, Toronto, Canada, 2007, pp. 1-8.

9. X. Ren, R. Lin, and H. Zou, "A Dynamic Load Balancing Strategy for Cloud Computing Platform Based on Exponential Smoothing Forecast,' in Proc. of 2011 IEEE International Conference on Cloud Computing and Intelligence Systems, Beijing, China, 2011, pp. 220-224.

10. Cadenas E, Jaramillo OA, \& Rivera W, "Analysis and Forecasting of Wind Velocity in Chetumal, Quintana Roo, using the Single Exponential Smoothing Method," Renewable Energy, vol. 35, no. 5, pp. 925-930, 2010.

11. Holt CC, "Forecasting Seasonals and Trends by Exponentially Weighted Moving Averages," International Journal of Forecasting, vol. 20, no. 1, pp. 5-10, 2004.

12. Gardner ES, "Exponential Smoothing: The State of the Art - Part II," International Journal of Forecasting, vol. 22, no. 4, pp. 637-666, 2006.

13. Hansun S, "A New Approach of Moving Average Method in Time Series Analysis," in Proc. of Conference on New Media Studies, Tangerang, Indonesia, 2013, pp. 1-4.

14. Johnston FR, Boyland JE, Meadows M, \& Shale E, "Some Properties of a Simple Moving Average when Applied to Forecasting a Time Series," Journal of the Operational Research Society, vol. 50, no. 12, pp. 1267-1271, 1999.

15. Asultanny Y, "Successful Forecasting for Knowledge Discovery by Statistical Methods," in Proc. of $9^{\text {th }}$ International Conference on Information Technology: New Generations, Las Vegas, USA, 2012, pp. 584-588.

16. Badan Pusat Statistik. Indeks Pembangunan Manusia menurut Provinsi, 2010-2016 (Metode Baru). [Online]. Available: https://www.bps.go.id/linkTableDinamis/view/id/1211.

17. Hansun S \& Kristanda MB. Phatsa (PHP Application for Time Series Analysis. [Online]. Available: http://phatsa.com. 


\section{AUTHORS PROFILE}

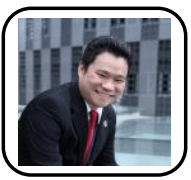

Seng Hansun had finished his Bachelor and Master degree from Universitas Gadjah Mada, majoring Mathematics and Computer Science program. Since

2011, he has been a lecturer and researcher at Universitas Multimedia Nusantara and published more than 75 papers both nationally and internationally. His research interests mainly in time series analysis and machine learning domain where he has successfully granted some research grants from the government and UMN institution.

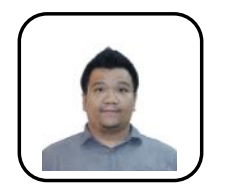

Marcel Bonar Kristanda lives in Jakarta, Indonesia. He received in Bachelor Degree in Computer Science (S.Kom) from Universitas Multimedia Nusantara, Tangerang, Banten, in 2011 and Master of Science in Information Management from Chinese Culture University, Taipei, Taiwan, in 2015. From 2011, he began his career in university as Assistant Lecturer, until he came back from his master study and became Lecturer in the Computer Science Department, Universitas Multimedia Nusantara. Then, he was entrusted to lead the Learning Center Department in 2016 and focused on developing E-Learning Platform and Development. His researches are based on his interests in mobile technology, mobile application development, web development, and software engineering. His extensive researches can be seen in several published papers in both national and international journals and conferences. 